\title{
Matthean Jesus and peacebuilding in Zimbabwe 2018-2019
}

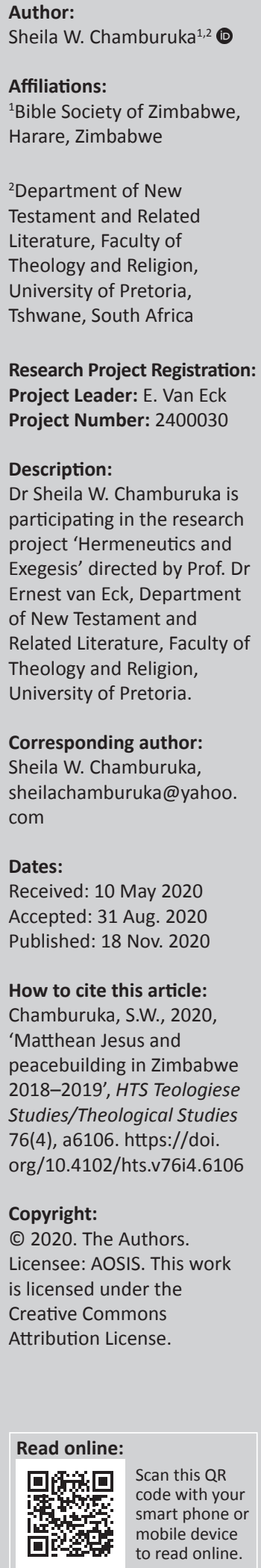

This article is an assessment of the applicability of the Matthean Jesus' ethics in the context of peacebuilding in Zimbabwe (2018-2019). The article explores the factors which led to the removal of former President Mugabe from the office, and the events which took place from 2018 to 2019. It is alleged that torture, brutality and political killings of people continue to resurface even during the leadership of the new President Emmerson Mnangagwa. Faced with the above challenges associated with violence, socio-political, economic and religious conflicts, civil unrest and polarisation of the Zimbabwean society, the article gives an analysis of the relevance and applicability of Jesus' ethics as presented by Matthew in a bid to bring national healing, peace and reconciliation in Zimbabwe. The ethics of Jesus are meant to transform society for the better; therefore, the article also assesses the lessons which can be drawn from these ethics amid challenges posed by a lack of confession, truth telling and transformative justice in the face of gross political intimidation and torture in Zimbabwe. The article concludes that the Matthean Jesus ethics are applicable in the Zimbabwean context. However, the implementation of these ethics faces serious impediments, which need special attention, especially the need of all citizens, government, political leaders, church leaders and civil society leaders to join hands together with the National Peace and Reconciliation Commission in bringing national healing in Zimbabwe.

Contribution: This article is part of the special collection 'Africa Platform for NT Scholars'. It focuses on the assessment of the applicability of the Matthean Jesus' ethics in the context of peacebuilding in Zimbabwe (2018-2019). The ethics of Jesus are meant to transform society for the better, therefore, it is within the scope of this theological journal that issues associated with violence, socio-political, economic and religious conflicts, civil unrest and polarization should be addressed, hence the article fits well within this scope.

Keywords: Matthean Jesus; Violence; Reconciliation; Justice; Peacebuilding; Zimbabwe.

\section{Introduction}

The focus of this article is to evaluate the applicability of the ethics of the Matthean Jesus in peacebuilding in Zimbabwe from 2018 to 2020. The key questions are as follows: (1) can we now talk of peacebuilding in Zimbabwe with the new leadership of President Emmerson Mnangagwa; (2) is the political environment conducive for truth telling, forgiveness, compensation and justice; (3) what does Matthew's Jesus say about peace? and (4) what is the role of the Church in Zimbabwe in peacebuilding? These questions will guide this discussion.

\section{Matthean Jesus and politics}

The Matthean Jesus' ethics refers to the ethics of Jesus on peacebuilding in the gospel of Matthew drawn mainly from Jesus' teachings in the Sermon on the Mount (Mt 5-7). In this section, we explore the Matthean conception of Jesus and his relation to politics. Riches and Sim (2005:139) argue that in Matthew, the political and healing aspects of the title Son of David comes into focus, and the centurion's confession of Jesus as Son of God has political, alongside its theological connotations. In Matthew, Roman soldiers acknowledge the healing power of Jesus and show deep faith in Jesus' ability to perform amazing miracles. Also, precisely at the point where Jesus is exposed to the military might of Rome, during his crucifixion, the agents of imperial power recognise in him a new and different kind of authority and power, as they confess him as the (true) son of God.

MacArthur (1985:xii) argues that the message of Matthew centres inter alia on the theme of Jesus' kingship, which is evident in the gospel of Matthew as the Messiah, a king whose claim is not

Note: Special Collection entitled Africa Platform for NT Scholars, sub-edited by Ernest van Eck (UP) 
accepted by his contemporaries and one who is to come again at the eschaton. His genealogy is associated with the kingship of Israel, but Herod felt threatened by his birth. However, aliens or gentiles welcome him as depicted by the story of the wise men (the magi) from the East who paid homage to his birth and presented him with gifts (Mt 2:1-12) (MacArthur 1985:xii). Keener (1999:80) asserts that the teaching of the Matthean Jesus is grounded and anchors on his Jewishness of audience as he is presented in royal overtones as king. This shows that the Matthean Jesus is enveloped in political overtones.

MacArthur (1985:xii) argues that the Sermon on the Mount is the major focus of Matthew functions as a manifesto of the Matthean Jesus, whose identity is characterised by performing miracles and teaching through parables which is a unique feature in his ministry. In the passion narratives, he presents futuristic eschatological claims that include his future reign and authority in heaven and earth (Mt 28:18) (MacArthur 1985:xii). Through this, Jesus saw himself as someone sent by God to rule the whole world. In Jewish culture, for someone to declare this, it showed that he was an aspiring politician.

Matthew uses the word Jews ('Iov $\left.\alpha \alpha^{\omega} \omega v\right)$ five times: four times to refer to Jesus as a king of Jews (Mt 2:2; Mt 27:11; 29, 37 ), and once in Matthew 28:15 in which the disciples of Jesus are falsely accused of stealing the body of Jesus by the Jews (MacArthur 1985:xii). The Matthean Jesus is presented as a rejected king in a peculiar way as compared with other three gospels (MacArthur 1985:xii). It is important to note that in all five instances of 'Iov $\alpha \alpha^{\prime} \omega v$ in Matthew, Jesus has no active, let alone violent role (Matthews \& Gibson 2005:85). In four of the references, they are the projected subjects of Jesus's rule, and in one reference, the object of the elite's information spin and bribes. Matthew neither constructs violence for the term 'Iov $\delta$ i' $\omega v$ nor does the noun 'I $\sigma \rho \tilde{\eta} \lambda$ in any of its 12 uses identify Israel as an agent of violence. That is, violence, and there is plenty of it in the gospel, is not identified with this ethnic group, although some interpreters tend to interpret it this way (Matthews \& Gibson 2005:85).

MacArthur (1985:xii), however, cites a number of instances in Matthew where Jesus is depicted in a political sense. For instance, in the birth narratives, Mary faces potential divorce by Joseph, and Herod is threatened by his birth and plots to kill him which leads the Holy family to seek asylum in Egypt. Moreover, as the Matthean Jesus starts his ministry, John the Baptist is imprisoned and martyred (MacArthur 1985:xii). This clearly shows that he was seen as a political concurrent. Consistent with a basic principle of Roman justice, namely, that punishment fits the societal (non) status of the person, Jesus's crucifixion serves to protect elite (Matthews \& Gibson 2005:93). ${ }^{1}$

\footnotetext{
1.In Matthew, the elite is comprised of those in leadership in alliance with non-Jews (e.g. kings, governors, Pilate) and the Jews (the Jerusalem elite; chief priests, Pharisees, scribes and the synagogues authorities)
}

The narrative of Jesus's ministry and crucifixion assumes and exposes a further dimension of violence, namely, the structural violence wrought by the vertical-imperial social order shaped, imposed and maintained by the elite (Matthews \& Gibson 2005:93). Jesus, when he started his public ministry proclaiming the kingdom of God, was not politically orientated, but his counterparts viewed him as an opposition candidate in matters pertaining to politics because of his proclamation (MacArthur 1985:xii).

The study of Jesus in the social, economic and political context of first-century Palestine does not necessarily indicate Jesus as an explicitly political figure. Politics and religion were more closely intertwined in the first century than they are today. In this sense, Jesus was undoubtedly a political figure, simply because of the impact of His religious views and actions. Malina (2001:64) indicates that amongst the statements of Jesus in the gospel story, some are direct challenges: he tells some Pharisees and their scribes 'you brood of vipers! How can you speak good, when you are evil? For out of the abundance of the heart the mouth speaks' (Mt 12:34; RSV). Jesus also labels the Pharisees and their scribes as 'an evil and adulterous generation' (Mt 12:39; 16:4; Mk 8:38; RSV). For persons who traced their honour to Abraham by pure genealogy, to be called 'snake bastards' and 'wicked bastards' would have provoked irrevocable enmity (Malina 2001:64). The same two categories are the objects in Matthew 23:13-29 with the refrain: 'How shameless you are, you that are rich'. Furthermore, violence by the elites aimed at Jesus is rhetorically (Mt 9:34; 12:24) and physically violent, mocking, flogging, crucifying and killing him (Mt 16:21; 17:22-23; 20:18-19; 26:27). They are even violent towards their own people (Mt 2:16-18). This violence includes physical killing (the Herod in Mt 2 and 14), predicts of crucifying, flogging and pursuit (Mt 10:17-18; 23:34) and verbal violence (reviling speaking evil falsely, Mt 5:10-12) (Matthews \& Gibson 2005:92).

There is clearly a difference in Matthew between Jesus and Pilate, Jesus and Judas of Galilee (often called the founder of the Zealots) and Jesus and Judas Iscariot, whatever the precise reasons were for Judas' betrayal (Marsh \& Moyise 2006:105). Matthew constructs the disciples of Jesus as nonviolent. The relational violence of Judas' and Peter's betrayals of Jesus (and the betrayal by all of the disciples in 26:56) is clearly not a model to be imitated (Matthews \& Gibson 2005:97). Whilst violent persecution of the disciples is presented as normative and inevitable (Mt 10:17-18; 13:21; 23:34), the disciples are forbidden to inflict violence on others (Matthews \& Gibson 2005:97). In the Sermon on the Mount, Jesus clearly declared that the use of violence was not to be the way of those committed to God's rule, and in Gethsemane, Jesus again explicitly rejects the option of violence (Stock 1994:408). Instead of continuing an endless and escalating chain of retribution, with violence spawning yet more violence ('all who take the sword will perish by the sword'; Mt 26:52), Jesus prophetically breaks the chain. His power is not of the sword (Stock 1994:408). 
The above discussion has indicated that Jesus was fully involved in politics. However, with some indications, he was an advocate of nonviolence. Therefore, it is paramount to discuss the arguments associated with Jesus as a peacemaker. This will help us to appreciate Jesus' role in advocating for peace.

\section{Matthew's Jesus as a peacemaker}

The Matthean Jesus encouraged his followers to be peacemakers and focused on unity of purpose based on the fact that God condemns a person who mistreats and hates his or her brother (Mt 5:21-22). Furthermore, the Matthean Jesus instructs his followers to make peace with their kinsman before they can present their gifts at the altar (Mt 5:23-24). Therefore, it is imperative for Christians to foster peace and unity and unconditionally promote reconciliation with their neighbours ahead of worship (Sande 1997:41).

It is important to note that (Sande 1997):

Matthew 7:5 ('Get the log out of your eye') suggests that peacemaking requires facing up to our own attitudes, faults and responsibilities before pointing out what others have done wrong. Overlooking the minor offenses of others and honestly admitting our own faults often will encourage similar responses from our opponents and open the way for candid dialogue, reconciliation and constructive negotiation. (p. 11)

\section{Sande (1997) asserts that:}

[T]he statement 'go and show your brother his fault' (Mt 18:15) shows that peace-making also requires constructive confrontation. When others fail to accept responsibility for their actions, we may need to confront them in a gracious, yet firm manner. (p. 11)

In the event that one fails to reform from their wrong actions, there must be efforts to seek the assistance of mediators who may include but not limited to respected friends, church leaders and other neutral individuals (Sande 1997:11). Some lessons that are drawn from Matthew 5:24 are that peacemaking is associated with commitment to resuscitate relationships and forging amicable solutions that are not discriminatory but just and satisfactory to parties involved in conflict (Sande 1997:11).

Peace is related to many dimensions of human life (Miller et al. 2007:38). Therefore, if one engages in peacebuilding, one should not be satisfied with only one dimension of peace. Peacebuilding takes place on many levels. Understanding peace as a continuum may help getting involved in peacebuilding. The continuum starts from humans' peace with God, and extends to peace with enemies. This continuum helps each of us to get involved in peacebuilding, because each of us can judge ourselves to see at what level we are already comfortable, and then strive for the next level. Someone might say that it is very hard for us to love our enemies. But people who find it hard to love enemies can still be involved in other levels of peacebuilding.
So everyone can be involved at some level (Miller et al. 2007:39).

Peacebuilding should start with peace with God. Many people admit that the horror of war and community conflict is so great that they often feel torn apart by what they see and hear on the field, even as they work for peace. Therefore, they have said, 'Without peace with God, we cannot talk about peace building, let alone to do peacebuilding'. Therefore, peace is not built outside and only then comes inside; it is the other way around. Peace always starts from within, subsequent to which it then ripples out. Peace starts with peace with God; but God, the source of peace, is also the God who wills peace for all creation (Miller et al. 2007:39). God does not want us to stay at the first level of peace with God. He wants us to move forward to the next level. We see this clearly in Jesus who demonstrated the way of peace. Jesus did not talk only about peace with him, but also about peace with families and neighbours; until we come to the most difficult part, peace with enemies. This is indeed difficult for us, especially if we have been hurt by people we then perceive them as enemies (Miller et al. 2007:39).

Barnette (1961:54) argues that Matthew 5:9, 'Blessed are the peacemakers' suggest that peace-making is another trait of kingdom people. They not only possess peace in their hearts, but also make peace amongst men. The blessing is on the peacemakers not the 'peace keepers'. As peacemakers they have a two-fold task: to work for the right relationships between God and man, and between man and man. This is the harmony with God's great work of reconciling men to himself. Peacemakers thus engage in what God does and therefore are called 'the sons of God'. Those who divide people are doing the devil's work; those who reconcile men are doing the God's work (Barnette 1961:54). This shows that Jesus was indeed a man of peace.

Hauerwas (1983:87) argues that Jesus proclaims peace as a real alternative, because he has made it possible to rest. The efficacy of the crucifixion and resurrection of Jesus is a manifestation and source of peace and forgiveness. This is the basis for the need to practice peace and forgiveness in our communities. Hauerwas (1983) asserts that:

$[W]$ hen we say we want peace, we mean we want order. Our greatest illusion and deception, therefore, is that we are a peaceable people so long as no one disturbs our illusions. (p. 144)

The idea of peace-making against revenge (Mt 5:38-42) suggests that it has by-now the familiar three parts: (1) the traditional teaching ('you have heard'); (2) Jesus' new command ('But I say to you') and (3) Jesus' little steps of creative ways to keep the command (using the examples of a slap, a suit, a mile and a ban) (Bruner 2004:246). A large part of the command gives disciples little practical ways to be peacemakers (the seventh beatitude). Jesus does not say impersonally, for example, whenever you are struck on the 
right cheek, offer the other also; and if you are sued for your shirt, give your coat as well. Rather Matthew's Jesus speaks much more personally. ${ }^{2}$

Is this kind of peace-building possible in the current Zimbabwe? One can start answering this question by turning to the events leading to the Zimbabwean 2018-harmonised elections.

\section{Events leading to 2018-harmonised elections in Zimbabwe}

With the events leading to 2018-harmonised elections, Zimbabwe was characterised by severe political violence which affected ordinary citizens (Zimbabwe Human Rights 2017). Various atrocities were perpetrated by police and the army and Harare was the most affected (Zimbabwe Human Rights 2017). Furthermore, the country experienced ugly intra- and inter-party violence within the period under review. For instance, it is alleged that the Movement for Democratic Change led by Morgan Tsvangirayi (MDC-T) party was involved in intra-party violence in Bulawayo. Rowdy members of the MDC-T youth wing violently disrupted a party meeting which resulted in the bodily injury of vice president Thokozani Khupe (Zimbabwe Human Rights 2017).

On the other political front, the battle to succeed Robert Mugabe intensified on 06 November 2017 after the aging Zimbabwean president Robert Gabriel Mugabe fired a longserving deputy (Emmerson Mnangagwa), long seen as his heir apparent (Thornycroft 2017). Emmerson Mnangagwa, who had served as vice president since 2014, and who was exiled alongside Robert Mugabe during the 1970s war against white minority rule, was fired on the 6th of November 2017 on allegations of disloyalty, disrespect, deceit and being unreliable to Mugabe (Thornycroft 2017). Mnangagwa, often referred to by his war-time name, Ngwena (crocodile), had long been tipped to succeed Mugabe when he died or retired (Thornycroft 2017). The announcement followed a weekend of public humiliation for Mnangagwa which was widely seen by some as a victory for Grace Mugabe, Zimbabwe's first lady, and a potential rival for the succession. Robert Mugabe did not realise or even think that firing Mnangagwa as vice-president and expelling him from the party were signals of his ruling as the President of Zimbabwe coming to an end.

On 19 November 2017, many Zimbabweans in their thousands thronged the street in most cites demonstrating against President Robert Mugabe and demanding his

2.This can be seen, for example, from Matthew 5:39-42: 'But I say to you, Do not resist one who is evil. But if any one (ootic) strikes you on the right cheek, turn to him

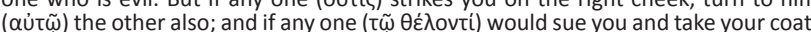
let him ( $\alpha \dot{\tau} \tau \tilde{\omega})$ have

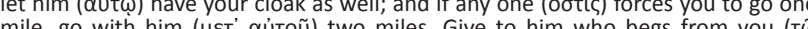
mile, go with him ( $\mu \varepsilon \tau$ ' aútoũ) two miles. Give to him who begs from you ( $\tau \tilde{\omega}$ altoovti), and do not refuse him who would borrow (tov $\theta \varepsilon \lambda_{0}$ ovta) from you'. Ther is, as indicated by Bruner (2004:247), an arresting personalism in all Jesus' socia commands, as can be seen in 'the brother' in the second, "the sister' in the third, the spouse in the fourth, the conversational partner in the fifth reinterpretation of the Law by Jesus in Matthew 5:21-48. immediate resignation, a spectacle that would have been unthinkable a few weeks earlier (Marima 2017). The march against Mugabe attracted people from many different backgrounds and races, ${ }^{3}$ and was a clear sign that people of Zimbabwe were fed up with the governance of Mugabe.

The statement of resignation by President Mugabe brought tremendous joy to the people of Zimbabwe. The streets of almost all cities in Zimbabwe were quickly flooded by jubilant people ululating, some blowing whistles and motorists hooting and some people coming out from their houses jumping, singing and dancing. The reaction by so many Zimbabweans showed that the long-awaited day of change had come. The Zimbabwe African National Union Patriotic Front (ZANU-PF) nominated Emmerson Dambudzo Mnangagwa to take up the presidium of Zimbabwe awaiting elections which would take place in the following year 2018. This was insinuated by the resignation of President Mugabe. Emmerson Mnangagwa was sworn in on Friday 24 November 2017 (The Herald 2017).

\section{Post Mugabe era 2018-2020}

In his inauguration speech at the National Sports Stadium in 2018, Mnangagwa advocated for peace and unity in Zimbabwe and pledged that he would want to rebuild relationships with the international community. Zimbabweans were waiting for a better Zimbabwe through the leadership of Mnangagwa. Though some of the people in Zimbabwe rejoiced because of the change in government, the question which still remained was: will Mnangagwa bring peace and reconciliation to Zimbabwe? Some people argue that Mnangagwa is the same as Mugabe because he was coming from the same ZANU-PF party and the same government. Inasmuch he had reshuffled the cabinet he did not change the majority of the people. He only removed people who were supporters of Grace Mugabe and replaced them with some people from the military. Some cabinet members only changed ministries. The purging of those who supported Mugabe throughout Zimbabwe was another cause of concern, because it was associated with violence, intimidation, beatings and various forms of political harassment. These socio-political challenges call for healing, peace and reconciliation in the post-Mugabe era.

In his inauguration speech, the new President also said 'Let the bygones be bygones. Let us preach love, unity, unity always' (The Zimbabwe Mail 2020).The people of Matabeleland, for example, were hoping that the coming of a new president of Zimbabwe will bring peace to their provinces in light of what had transpired before, for

3.Anesu Dawa, a 26 -year-old unemployed graduate, told Al Jazeera that 'everybody came out just to say it is not necessarily what we want it to happen, but it is what we do not want to happen for President Mugabe to be still the president of Zimbabwe. And we all agreed today that he must go'. Florence Mguni, a 59-year-old who went to train in Mozambique as a liberation fighter at the age of 15, travelled overnight from Bulawayo in the hope of witnessing Mugabe's departure. Mguni told Al Jazeera that as a war veteran, she demands Mugabe's immediate resignation because his leadership has done little for her. She argued that we 'went to fight in the war, I was taught how to hold a gun as a young girl, but today Zimbabwe is free and I am poor. I'm a widow and my children are not in school because I cannot always afford to pay their fees' (Al Jazeera 2017). 
example, the Gukurahundi massacres happened which targeted largely the Ndebele ethnic group who reside in the Midlands and Matabeleland provinces. Over 20000 people were butchered by the North Korean trained Fifth Brigade, have been pushing for reparation (Mushava 2020).

Chief Felix Ndiweni, speaking during the launch of a documentary titled 'Gukurahundi Genocide: 36 years later' reiterated that the atrocities committed during the Gukurahundi genocide should be addressed in order for the country to heal and move on. He further encouraged the surviving victims of the genocide to share their story. He further alluded that genocide is the deepest pain ever to be traced in men and it ought to be treated differently, it is not static but progressive (Ngwenya 2018). After his comments, he was tortured and even imprisoned because he was seen as a threat by trying to raise emotions of people in Matabeleland on the issue of Gukurahundi. For the government, to mitigate the issue was to imprison him. Hence, the long-awaited apology from the president never happened.

This makes it difficult for peacebuilding to be practical in the nation of Zimbabwe. Nyati, speaking against the statement of President Mnangagwa, argued that 'It is not possible in the environment we are in to talk about letting bygones be bygones'. We have to get to the bottom of all the violence that has taken place in the country of Zimbabwe in the past and look at the environment we are in right now as a nation. Nyati further reiterated that 'It is violation of the constitution that established the National Peace and Reconciliation Commission (NPRC). Anyone who advocates for bygones to be bygones is promoting impunity' (Amnesty International 2020). These statements by Nyati clearly indicate that the people of Zimbabwe are still traumatised by the events that took place previously and therefore, President Mnangagwa needs to take serious consideration of the fact of national healing and peacebuilding in Zimbabwe.

Zimbabwe held harmonised elections on 30 July 2018, whose outcome had to be decided by the courts. Since the election of Mnangagwa took place, the opposition party Movement for Democratic Change-Alliance (MDC-A) led by Nelson Chamisa has been questioning the legitimacy of Emmerson Mnangagwa as the president of Zimbabwe. For them, the presidential election results were tampered with by the Zimbabwe Electoral Commission (ZEC), which took time to announce the results and more so that the figures which were announced were not tallying with those from the constituencies. The opposition party also questioned the outcome of results in courts, but it did not yield results since the court ruling favoured the ruling party ZANU-PF led by Mnangagwa. The court declared that the election of Mnangagwa was done free and fair and therefore he was the legitimate leader of Zimbabwe. This worsened the situation in Zimbabwe, since the opposition party MDC-A became very emotional because of the court ruling. They tried everything that included demonstrations in the streets but all those who were leading the demonstrations were tortured and put in prison and some were even killed by the soldiers.

On 14 January 2019, Zimbabwe witnessed political brutality in the history of the new government in the post-Mugabe era in which eight civilians were shot and killed by the army during a 3-day national protest that was organised by the Zimbabwe Congress of Trade Unions (ZCTU).The protests were triggered by the hiking of fuel prices which was announced by President Mnangangwa on national television. The police and the army used excessive force in dealing with protesters and this resulted in the loss of lives and severe injuries in major cities countrywide (Kubatana 2018).

The president of Zimbabwe signed the NPRC Bill into the law on 05 January 2019, making operational the commission that was appointed 2 years ago (Tshuma 2019a:22). According to Murambadoro (2019), NPRC, which was a product of the National Peace and Reconciliation Act of 2018, has limitations because of the lack of adequate political and legal power and this resulted in the conflicts associated with several injustices experienced by Zimbabwean masses. The new government has a mandate to create a conducive environment in order to facilitate healing and reconciliation with a well-defined transitional justice, which covers both the perpetrators and victims of past injustices. Moreover, the church must also seize opportunity to complement the work of the NPRC by proffering the Matthean Jesus' ethics in the process of peacebuilding in Zimbabwe.

It is evident that an upsurge of the tension between the new Zimbabwean government and its citizens is going to increase; hence, the NPRC should be well resourced and empowered in order to reduce and possibly prevent the resurgence of injustices and politically motivated violence (Kubatana 2018). However, the efforts by the government to facilitate peacebuilding is most likely to succumb to failure because it is not creating a conducive and enabling environment such as the roping in of neutral facilitators of this process which include churches because they have the capacity to employ biblical principles which are indispensable in ushering sociopolitical integration. According to Kubatana (2018), Zimbabwe can draw meaningful lessons from how countries like South Africa and Rwanda dealt with their past injustices through the creation of peace commissions and courts which effectively addressed these problems.

It is imperative to note that Zimbabwe has experienced a sad and unfortunate past and present in which political differences, be it intra or inter party, are resolved more often than not, by violent means. There is a lack of political maturity which translates into political intolerance. This is a challenge for the application of the Matthean Jesus' ethics. According to Ndlovu-Gatsheni and Benyera (2016:18) 'whatever mechanisms and methodologies are employed to achieve justice and reconciliation, must be capable of engaging with 
the historical legacies of conflict and violence'. The opposition leader of the MDC-A, Nelson Chamisa, has argued that the NPRC should be independent and autonomous. He stated that the continued culture of impunity in the country, in spite of the existence of the commission, as well as the disturbing fact that the NPRC had not referred anyone for prosecution, even in cases where the culprits of violence and conflicts had been identified, does not spell good for reconciliation in Zimbabwe (Tamborinyoka 2019).

In the Zimbabwean context, the work of the NPRC as an independent body with the mandate to facilitate national peace and healing through political dialogue was dampened and overshadowed by the president when he created the Political Actors Dialogue (POLAD). This initiative was supported by small political parties who quickly joined POLAD. However, Nelson Chamisa, leader of MDC-A, the main opposition party, rejected and vowed that his party will not participate in POLAD because it was led by President Mnangagwa whom according to them lacks political legitimacy (Tshuma 2019b). For MDC-A, Mnangagwa manipulated his victory of the 2018 elections, hence they question his legitimacy. Hence, there was a call for a neutral mediator in the political dialogue in Zimbabwe but President Mnangagwa refuted this call and maintained that he will only consider POLAD as the legitimate platform of any political dialogue. This shows that there is a serious deadlock in Zimbabwean politics and the application of Matthean Jesus ethics in facilitating peacebuilding may break this impasse if afforded a chance.

\section{Conclusion}

From the discussions above, one can argue that the Zimbabwean context still needs peacebuilding. The application of Matthean Jesus' ethics in Zimbabwe is still a long way to be attained because of a low-profile involvement of the church in the work of the NPRC. The church is instrumental in the application of Jesus' ethics in peacebuilding and national healing. Politicians have become the major stumbling block for churches to fully participate in the process. Jesus was a peacemaker as indicated in this article, however, a lack of truth telling and justice has hindered meaningful progress. The continued brutality and torturing of people in the nation will make it difficult for the NPRC to do what they are supposed to do because even old wounds are continuously being reopened. Jesus spoke of loving one another unconditionally, but this ethic is also difficult to implement as the two main political parties in Zimbabwe are irreconcilable. The Zimbabwean community, through church, political and civil society leaders, need to join hands and imitate Jesus by promoting peacebuilding and reconciliation, truth telling and justice. They should put Zimbabwean interests first and commit themselves to peacebuilding. Over and above this, constitutionalism and the rule of law must be enforced if peacebuilding initiatives are to succeed. Lastly, the church must assume a prophetic role and become the voice of the voiceless.

\section{Acknowledgements Competing interests}

The author declares that they have no financial or personal relationships that may have inappropriately influenced them in writing this research article.

\section{Author's contribution}

S.W.C. is the sole author of this research article.

\section{Ethical considerations}

This article followed all ethical standards for research without direct contact with human or animal subjects.

\section{Funding information}

This research received no specific grant from any funding agency in the public, commercial or not-for-profit sectors.

\section{Data availability}

Data sharing is not applicable to this article as no data were created or analysed in this study.

\section{Disclaimer}

The views and opinions expressed in this article are those of the author and do not necessarily reflect the official policy or position of any affiliated agency of the author.

\section{References}

Al Jazeera News, 2017, 'Zimbabwe army operation led Mugabe ouster ends', viewed 29 November 2017, from https://www.aljazeera.com/news/2017/11/zimbabwearmy-operation-led-mugabe-ouster-ends-171127095257351.html.

Amnesty International, 2020, 'News updates', viewed 20 April 2020, from http//www. amnesty.org/en/news-and-updates.

Barnette, H.H., 1961, Introducing Christian ethics, Broadman Press, Nashville, TN.

Bruner, F.D., 2004, Matthew: A commentary vol. 1, Mt 1-12, WM. B. Eerdmans, Grand Rapids, MI.

Hauerwas, S., 1983, The peaceable kingdom, A primer in Christian ethics, University of Notre Dame, Notre Dame.

Keener, C.S., 1999, Matthew: A commentary on the gospel of Mathew, WM. B. Eerdmans, Grand Rapids, MI.

Kubatana, 2018, Heal Zimbabwe, viewed 20 April 2020, from http://www.facebook. com/kubatana/posts/2200733683271352? ref $=104$

MacArthur, J.F., 1985, The MacArthur New Testament commentary Matthew 1-7, Augsburg Press, Chicago, IL.

Malina, B. J., 2001, The social gospel of Jesus: The Kingdom of God in Mediterranean perspective, Augsburg Fortress, Minneapolis, MN.

Marima, T., 'Zimbabwe: Army operation that led to Mugabe ouster ends', Aljazeera, viewed 29 November 2020, from https://www.aljazeera.com/news/2017/11/27/ zimbabwe-army-operation-that-led-to-mugabe-ouster-ends.

Marsh, C. \& Moyise, S., 2006, Jesus and the gospels, T\&T Clark, New York, NY.

Matthews, S. \& Gibson, E.L., 2005, Violence in the New Testament, T\&T Clark International, New York, NY.

Miller, D.E., Holland, S., Johnson, D. \& Fendall, L., 2007, Seeking peace in Africa: Stories from African peacemakers, Cascadia Publishing House, Telford.

Murambadoro, R., 2019, One year after: Has the national peace and reconciliation commission act failed Zimbabweans?, viewed 30 April 2020, from http://kujengaamani.ssrc.org/2019/02/07/one-year-after-has-the-national-peace-andreconciliation-commission-act-failed-zimbabweans/.

Mushava, E., 2020, 'Political polarisation hurting NPRC work', The Zimbabwe Daily, viewed 29 April 2020, from https://www.thezimbabwedaily.com/news/388190political-polarisation-hurting-nprc-work.html.

Ndlovu-Gatsheni, S.J. \& Benyera, E., 2016, Towards a framework for resolving the Justice and reconciliation question in Zimbabwe, viewed 20 March 2020, from 
https://www.accord.org.za/ajcr-issues/towards-a-framework-for-resolving-thejustice-and-reconciliation-question-in-zimbabwe/.

Ngwenya, L., 2018, Gukurahundi atrocities must be addressed, viewed 23 April 2020 from http://www.cite.org.zw/gukurahundi-atrocities-must-be-addressed-chiefndiweni/.

Riches, J. \& Sim D.C., (eds.), 2005, The Gospel of Matthew in its Roman Imperial context, T\&T Clark International, London.

Sande, K., 1997, The peacemaker, A biblical guide to resolving personal conflict, Baker Books, Grand Rapids, MI.

Stock, A., 1994, The method and message of Matthew, Liturgical Press, Collegeville, MI.

Tamborinyoka, L., 2019, Zimbabwe DC leadership engages National Peace and Reconciliation Commission, viewed 15 April 2020, from http:cpnn-world.org/ news/?p=18451

The Herald, 2017, Zanu-PF recalls president Mugabe, viewed 17 March 2020, from https://www.herald.co.zw/zanu-pf-recalls-pres-mugabe.
The Zimbabwe Mail, 2020, Mnangagwa's 'bygones' call dismissed as nonstarter viewed 25 April 2020, from http://www.thezimbabwemail.com/politics/ mnangagwa-bygones-call-dismissed-as-non-starter.

Thornycroft, P., 2017, Robert Mugabe fires vice president as Zimbabwe's succession battle intensifies, viewed 06 April 2020, from www.telegraph.co.uk/news/ 2017/11/06/robert-mugabe-firesvice-president-zimbabwe-succession-battle.

Tshuma, D., 2019a, Healing the wounds of the past, viewed 30 April 2020, from https://www.accord.org.za/conflict-trends/healing-the-wounds-of-the-past.

Tshuma, D., 2019b, Reconciliation, integration and healing efforts in Zimbabwe, viewed 30 April 2020, from https://www.accord.org.za/conflict-trends/ reconciliation-integration-and-healing-efforts-in-zimbabwe/.

Zimbabwe Human Rights NGO Forum, 2017, Predisposing the scourge of political violence, 09 August 2017, viewed 20 April 2020, from http://www.humanrights. uio.no/forskning/publ/publikasjonsliste.htm. 